\title{
The effect of Lactobacillus acidophilus cell free extract on micronuclei in white male mice
}

\author{
تأثير مستخلص الخلايا الحر لـ Lactobacillus acidophilus على تكوين النوى ألفور \\ الصغيرة في ذكور الفئران البيضاء
}

Ruqaya M. Al-Ezy , Niran A. Ibraheem*, Ebtehal H.Al-Naimy**, Maysaa Ch. Al-Yas

Biotechnology Department /College of Science/ Al -Nahrain University.

* Biology Dept. /Ibn-Alhaitnam / Baghdad University

**Biotechnology Research Center / Al -Nahrain University.

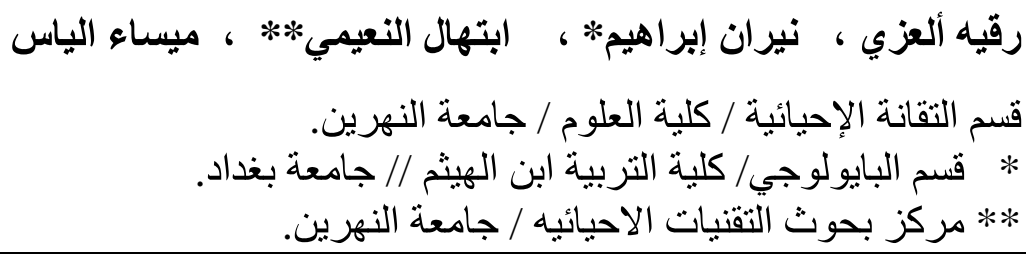

Abstract:

This study dealt with the effect of Lactobacillus acidophilus concentrated filtrate on polychromatic erythrocyte. The result showed that Lactobacillus acidophilus concentrated filtrate caused a non significant decrease in micronucleus formation at first dose in comparison with negative control while a significant decrease in micronucleus formation was shown in albino male mice at second and third doses in comparison with negative and positive controls. The result of post-treatment by concentrated filtrate also caused a significant decrease in micronucleus formation while the pre-treatment caused non significant decrease in the micronucleus formation in comparison with the corresponding control.

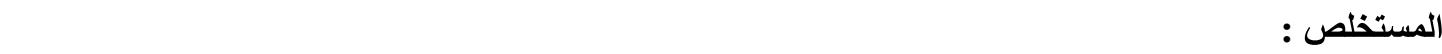

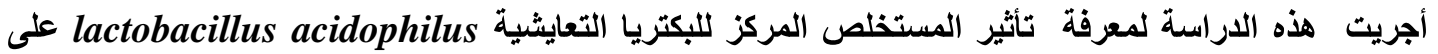

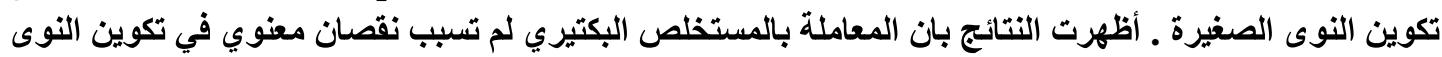

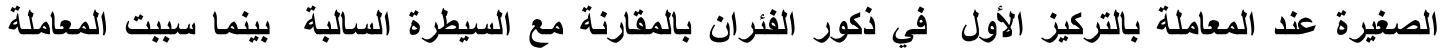

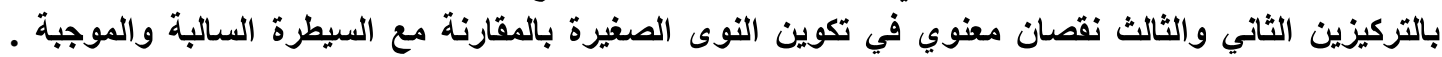

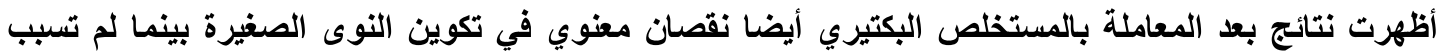

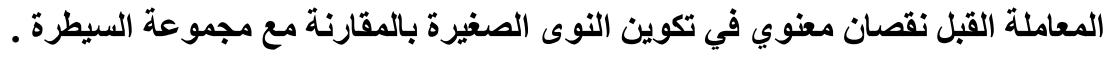




\section{Introduction}

Cytogenetic analyses have been employed widely to detect the effect of mutagens and carcinogens on the genetic make-up. This is carried out using in vivo and in vitro systems. Chick embryos were the first to be utilized in vivo analysis [1], but later mice became the animals of choice in such experiments due to their fast reproduction, small size and easy handling, moreover, they represent a typical mammalian system [2]. In vitro studies generally employ live cells of a mammalian origin, and in this regard the lymphocytes are the cells of choice in investigating the mutagenic effects of some agents [3].

Micronuclei are cytoplasmic chromatin masses with the appearance of small nuclei that arise from chromosome lagging at anaphase or from accentric chromosomal fragments [4]. Some scientist [5] employed the micronucleus assay to measure the cytogenetic damage induced in the dividing cells of root tips by fast neutrons and X-ray in the presence and absence of oxygen.

Schroder $[6,7]$ recommended the use of bone marrow smears to detect in vivo genetic damage induced by chemical mutagens and demonstrated the occurrence of micronuclei in bone marrow cells in connection with cytogenetic damages. Many researchers have studied the biological basis of the antitumour effect of dietary lab in various animal models for human cancer.

\section{Materials and methods}

\section{Laboratory Animals}

Albino male mice (Mus musculus) were used to carry out the investigations of the present study. They were obtained from Biotechnology Research Center (Al-Nahrain University). Their age range was 8-9 weeks, and their weight was 23-27 grams at the beginning of experiments. They were caged in the animal house of the supplier, in which the temperature was 23-26 C , and a light: dark periods of 10:14 hours/day. The animals had free excess to food (standard pellets) and drinking water (ad libitium) during all experiments.

\section{Experimental Design}

Three doses of Lactobacillus acidophilus concentrated filtrate were carried out to assess the cytogenetic effects of cell free extract of Lactobacillus acidophilus, and their effects in modulating the effects of the drug cyclophosphomide in albino male mice, therefore, such evaluations were carried out through two stages.

First Stage

In this stage, cytogenetic effects were carried out by micronucleus formation of three doses of Lactobacillus acidophilus concentrated filtrate and cyclophosphomide were investigated. Therefore, the animals were divided into three groups:

Group I: The animals were given distilled water (negative controls $=8$ animals).

Group II: The animals were treated with cyclophosphomide at a dose of $15 \mathrm{mg} / \mathrm{kg}$ (positive controls $=8$ animals)

Group III: The animals were treated with three doses of the Lactobacillus acidophilus concentrated $(250,500$ and $750 \mathrm{mg} / \mathrm{kg})(24$ animals $)$. 
Lactobacillus acidophilus concentrated filtrate were given to mice groups orally $(0.1 \mathrm{ml})$ per day for 7 days. Then the mice were sacrificed in day 8 for laboratory assessments. The total number of mice in this stage was 72 animals.

\section{Second Stage}

In this stage, interactions (pre- and post-treatments) between the ideal dose of Lactobacillus acidophilus concentrated filtrate $(250 \mathrm{mg} / \mathrm{kg})$ and cyclophosphomide (15 $\mathrm{mg} / \mathrm{kg}$ ) [8] were carried out. The criterion of selection for the ideal dose was based on the approximation between the values of micronucleus formation in the extract-treated animals and negative controls.

- In pre-treatment interaction, the Lactobacillus acidophilus concentrated filtrate was given for 6 days (single dose/day), while cyclophosphomide was given in day 7 , and then animals were sacrificed in day 8 for laboratory assessments. In both cases, the materials were given orally $(0.1 \mathrm{ml})$. The total number of mice in this interaction was 32 animals.

- In post-treatment interaction, the animals was given cyclophosphomide on the first day, while the Lactobacillus acidophilus concentrated filtrate was given in the $2^{\text {nd }}$ day till day 7 (single dose/day), and then animals were sacrificed in day 8 for laboratory assessments. In both cases, the materials were given orally $(0.1 \mathrm{ml})$. The total number of mice in this interaction was 32 animals.

\section{Micronucleus Test}

The procedure of [9] was followed with some modification to assess the micronucleus formation in the bone marrow of mice. The animal was sacrificed by cervical dislocation, and the femur bone was removed and cleaned from muscles and other tissues, and both ends were cut. Then, the bone was griped from the middle with forceps in a vertical position over the edge of a test tube, and $2 \mathrm{ml}$ of $\mathrm{AB}$ human plasma (heat inactivated) were injected in the bone cavity to wash out the bone marrow cells, using insulin syringe. The test tube was centrifuged at $(1000 \mathrm{rpm})$ for $5 \mathrm{~min}$, and after discarding the supernatant, the cell deposit was smeared on a clean slide, which was air-dried. The smear was fixed with absolute methanol, stained with Giemsa stain for 15 minutes, then washed with distilled water, and air-dried.

The slide was examined under oil immersion lens (100X), and polychromatic erythrocytes (PCE) were inspected for the formation of micronucleus. A total of 1000 cells were randomly examined, and the micronucleus index was calculated using the following equation:

Micronucleus index $($ micronucleus $/$ cell $)=\frac{\text { Number of Micronuclei }}{\text { Total Count of PCE }}$

\section{Results:}

\section{Micronucleus formation}

The frequency of micronucleus formation in negative control was (0.007 micronucleus /cell). There are non significant decrease in number of micronucleus formation in mice treated with Lactobacillus acidophilus concentrated filtrate for all three doses $(250,500$ and $750 \mathrm{mg} / \mathrm{kg})$ to reach to $(0.0058,0.0033$ and 0.0038 Micronucleus /cell) respectively, 
howver, there are significant increase in the frequency of micronucleus formation in mice treated with cyclophosoamide in compartion with the negative control. $(0.0153$ vs. 0.007 micronucleus /cell).

\section{Concentrated filtrate of Lactobacillus acidophilus - cyclophosphomide interactions}

Two types of interactions (pre-and post- treatment) were carried out between the ideal dose of Lactobacillus acidophilus concentrated filtrate and cyclophosphomide to evaluate the role of the concentrated filtrate in modulating the cytological effect of the drug in albino male mice. The selection of ideal dose was based on the results of micronucleus formation as indicated in table (1) in which no significant differences was observed between the concentrated filterate treated mice and negative control.

Table (1): Micronucleus formation in bone marrow cells (mean \pm standard error) of albino male mice treated with Lactobacillus acidophilus concentrated filtrate, distilled water and cyclophosphomide drug

\begin{tabular}{|c|c|c|c|c|c|}
\hline \multicolumn{2}{|r|}{ Groups } & $\begin{array}{c}\text { Dose } \\
(\mathrm{mg} / \mathrm{kg})\end{array}$ & $\begin{array}{c}\text { Mean } \pm \\
\text { Standard Error } \\
\text { Mn/cell }\end{array}$ & $\begin{array}{c}\text { Treatment } \\
\text { Efficiency } \\
(\%)\end{array}$ & $\begin{array}{l}\text { Statistical } \\
\text { Evaluation }\end{array}$ \\
\hline \multicolumn{2}{|c|}{$\begin{array}{l}\text { Positive Control } \\
\text { (cyclophosphomide Drug) }\end{array}$} & 15 & $0.0153 \pm 0.0012$ & 117.85 & B \\
\hline \multicolumn{2}{|c|}{$\begin{array}{l}\text { Negative Control (Distilled } \\
\text { Water) }\end{array}$} & 0.00 & $0.0070 \pm 0.0003$ & & A \\
\hline \multirow{3}{*}{ 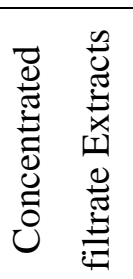 } & First dose & 250 & $0.0058 \pm 0.0005$ & -17.85 & A \\
\hline & Second dose & 500 & $0.0033 \pm 0.0010$ & -53.57 & $\mathrm{C}$ \\
\hline & Third dose & 750 & $0.0038 \pm 0.0004$ & -46.43 & $\mathrm{C}$ \\
\hline
\end{tabular}

Different letters in the same column: significant difference $(P \leq 0.05)$ between mean

\section{Micronucleus index}

In the pre-treatment interaction with the concentrated filtrate of Lactobacillus acidophilus $(250 \mathrm{mg} / \mathrm{kg})$, there are non significant reduction in micronucleus formation as compared to the corresponding control (0.0067 vs. 0.0070 micronucleus/cells). In contrast, the post treatment was effective in this regard, a significant reduction in micronucleus formation was observed as compared to the corresponding control (0.0040 vs. 0.0120 micronucleus/ cells). Table (2). 
Table 2: Micronucleus formation of bone marrow cells (mean \pm standard error) in albino male mice after interactions (pre- and post-treatments) between the ideal dose $(250 \mathrm{mg} / \mathrm{kg})$ of concentrated filtrate of Lactobacillus acidophilus and cyclophosphomide drug.

\begin{tabular}{|c|c|c|c|c|}
\hline \multirow[t]{2}{*}{ Groups } & \multicolumn{2}{|c|}{$\begin{array}{c}\text { Mean } \pm \text { Standard Error } \\
\text { Mn/cell }\end{array}$} & \multicolumn{2}{|c|}{$\begin{array}{c}\text { Treatment Efficiency } \\
(\%)\end{array}$} \\
\hline & $\begin{array}{c}\text { Pre- } \\
\text { treatment }\end{array}$ & $\begin{array}{c}\text { Post- } \\
\text { treatment }\end{array}$ & $\begin{array}{l}\text { Pre- } \\
\text { treatment }\end{array}$ & $\begin{array}{c}\text { Post- } \\
\text { treatment }\end{array}$ \\
\hline $\begin{array}{lll}\text { Control } 1 & \text { (Distilled } \\
\text { Water } & \\
\text { cyclophosphomide) }\end{array}$ & $\begin{array}{l}0.0070 \pm 0.0 \\
021 \mathrm{a}\end{array}$ & $\begin{array}{l}0.0210 \pm 0 \\
.0004 \mathrm{a}\end{array}$ & & \\
\hline $\begin{array}{l}\text { Control } 2 \\
\text { (concentrated filtrate }+ \\
\text { cyclophosphomide) }\end{array}$ & $\begin{array}{c}0.0067 \pm 0.0 \\
011 \mathrm{a}\end{array}$ & $\begin{array}{c}0.0040 \pm 0 \\
.0004 \mathrm{~b}\end{array}$ & & \\
\hline
\end{tabular}

Different letters in the same column: significant difference $(P \leq 0.05)$ between means.

\section{Discussions}

The function of immune system is genetically determined, and alternations (mutations) in the genetic make-up of animals do have their effect on such function [10]. To explore the effects of concentrated filtrate of Lactobacillus acidophilus on the genetic make-up of mice directly or through interactions with the drug cyclophosphomide, the assessment that was carried out; were micronucleus formation in polychromtic cells of bone marrow , which was good parameter of mutagenic evaluations [11,12]. The results of genetic evaluations showed that a treatment with concentrated filtrate of Lactobacillus acidophilus was associated with a significant reduction in micronucleus formation and such effect was dependent on dose. Such findings can be considered important, especially if we consider that most cancers are preceded by mutations induced by different agents, especially those that have oxidant effects $[13,14]$. However, the mechanisms are not the same for different types of tumour. In addition, therapeutic antitumour effect by Lactobacillus acidophilus concentrated filtrate differs as a function of dose, time of administration and the route of injection that are chosen.

\section{References}

1. Bloom, S. E. and Hsu, T. C. (1975). Differential fluorescence of sister chromatids in chicken embryos exposed to 5-bromodeoxyuridine. Chromosama, 51: 261-267.

2. Haung, C. C.; Jan, J. C.; Pacholec, P. D. and Chapman, V. M. (1990). Comparison of base line sister chromatid exchanges (SCE), cyclophosphamide-ethylnitrosourea (ENU), induce cell cycle delay and chromosome aberrations between Peru and laboratory mice. Mutation Research, 230: 93-100.

3. Nath, J. ; Krishna, G.; Petersen, M. and Ong, T. (1988). Sister chromatid exchanges induced by triethyleneamine: in vivo and in vitro studies in mouse and Chinese hamster bone marrow and spleen cells, Mutation Research, 206: 73-82. 
4. Tian, Y.; Ishikawa, H.; Piao, F. Y.; Yamamoto, H.; Yamauchi, T.; Duan, Z. W.; Zhany, Y. M.; Ma, M. Y.; and Cui, J. S. ( 2003 ). Micronucleus assay of human Capillary blood lymphocytes methods. Occupational Health Nursing Journal, 45: 408-409.

5. Evans, H. J.; Neary, G. J. and Williamson, F. S. (1959). International Journal of Radiation Biology, 1: 216-229.

6. Schroder, T. M. (1966) Human Genetic. 2: 287-3116.

7. Schroder, T. M. (1970). Chemical mutagenesis in mammals and man, Springer, Heideberg, pp. 214-219.

8. Tesxeira,R.D. ;Camparota, M.H. ;Mantovani, M. S. and Vicentini, V.E.P.(2003).Assesment of two medicinal plants , Psidinal guajava L., and Achillea millefoliul L., in vitro and in vivo assays. Genet .Mol. Biol.26:4.

9. Schmid, W. (1976). The cell micronucleus test for cytogenes analysis in: Hollaender, A. (Ed.) Chemical Mutagens principles and Methods for their Detection. Volume Four. Plenum Press, New York and London. pp:31-53.

10. 10-Abbas, A. K. and Lichtman, A. H. (Editors) (2003). Cellular and Molecular Immunology, $5^{\text {th }}$ Edition. Elsevier Science (U.S.A.) pp. 1-16.

11. 11-Ghaskadbi, S, and Vaidya, V. G. (1991). Studies on modulation of the effects of colchicine by L-cysteine using bone marrow of swiss mice. Mutation Research, 260:181-185.

12. 12-Al-Rubaiey, F. A. A. (2000). A study of the mutagenic and antimutagenic ability of some Iraqi medicinal plants. M.Sc. Thesis, College of Education/ Ibn AlHaitham/University of Baghdad/Iraq.

13. 13-Yaseen, N. Y. (1990). Cytogenetic study of human colorectal cancer. Ph.D. Thesis/University Sheffield. U. K..

14. 14-Ad'hiah, A. H.; Al-Kashaly, S. S. and Abbas, T. A. A. (2002). Group A streptococcus (Streptococcus pyogenes) and the mitotic activity of lymphoid organs in albino mice. The Eight Scientific Conference of the Technical Education Committee, pp. 302-208. 